ON TRACK

\title{
A Way Forward for Health Care and Healers
}

\author{
Robin S. Gotler, MA, Reflections Editor \\ Kurt C. Stange, $M D, P b D$, Editor \\ Ann Fam Med 2009;7:273-274. DOI: 10.1370/afm.988.
}

$\mathrm{T}$ The reaction' to Egnew's essay "Suffering, Meaning, and Healing: Challenges of Contemporary Medicine $^{\prime \prime 2}$ reveals deep yearnings and strong convictions among clinicians, patients, and medical students. Clinicians describe a yearning for an integrative approach to medicine in which "relational wisdom and clinical wisdom [are] inextricably tied together ${ }^{1 / 3}$ so that we can "reclaim our own souls, and... learn to heal again." ${ }^{4}$ On an individual level, this requires self-awareness ${ }^{5}$ and a willingness to provide patients with space in which healing can take place. ${ }^{6}$ On a broader level, it requires medical training that emphasizes patient centeredness ${ }^{7}$ and the ability not only to communicate but to connect. ${ }^{6}$ In addition, according to a medical student, role models of physician healers "are essential to counteracting the sometimes unhealthy pressures we face as students." ${ }^{\text {P }}$ Patients describe the transformative power in self-defined healing, ${ }^{9}$ and they challenge us to develop language that reflects a true partnership between clinicians and beneficiaries of care. ${ }^{10}$ Family medicine, which sprang from a desire to revolutionize care, may be a natural home for the physician-healer movement, according to Farber: "My hope is the old revolutionaries of Family Medicine will join forces with the new revolutionaries of Palliative Care to further move us along the path of training and supporting physician healers." ${ }^{11}$

This powerful essay and compelling discussion light an undeniable path forward to re-form health care, starting with ourselves, to reduce suffering, restore meaning and promote true healing. Consider reading the essay and discussion on paper, away from your computer, but close to your heart. Then, consider how you can begin the inner transformation and external action that these words compel.

\section{MORE HIGHLIGHTS}

The rich online discussion also includes suggestions for:

- Overcoming fragmented health care ${ }^{12}$

- Refocusing generalists and specialists on their most effective and efficient roles and shared care ${ }^{13}$

- Using listening and relationship rather than tests to foster a sense of patient well-being ${ }^{14}$
- Implementing incentives so that they do more good than harm ${ }^{15}$

- Improving maternity care access and comprehensivenes ${ }^{16,17}$

- Reframing our interpretation of the effect of personality on study data completeness ${ }^{18}$

- Making the cholesterol-lowering benefits of barley tolerable ${ }^{19}$

- Improving quality of care ${ }^{20}$

- Improving communication with a pause during care and by reforming care away from only brief encounters ${ }^{21}$

- Understanding how important health literacy is to effective health care ${ }^{22}$

- Approaching the multifactorial nature of asthma and its multilevel treatment ${ }^{23}$

- Overcoming underrecognition of the impact of direct-to-consumer advertising on the outpatient visit and prescribing ${ }^{24}$

- Fanning or slaking turf wars around who should perform colonoscopy ${ }^{25}$

- Assessing the trade-offs involved in using short or long instruments to screen for postpartum depression ${ }^{26}$

- Implementing processes for detecting and managing post-myocardial infarction depression ${ }^{27}$

- Reconsidering relevancy and bureaucratic load of the National Committee for Quality Assurance assessment of the patient-centered medical home concept ${ }^{28}$

- Understanding uncertainty ${ }^{29}$

- Considering the trade-offs in paper vs electronic data collection in office-based research ${ }^{30}$

We were delighted to see the comments of a residency journal club. ${ }^{31}$ We encourage other local journal clubs, and all readers, to join the discussion at http:// www.AnnFamMed.org

\section{References}

1. TRACK discussion in response to: Egnew TR. Suffering, meaning, and healing: challenges of contemporary medicine. Ann Fam Med. 2009;7(2):170-175. http://www.annfammed.org/cgi/eletters/7/2/170 Accessed Apr 6, 2009.

2. Egnew TR. Suffering, meaning, and healing: challenges of contemporary medicine. Ann Fam Med. 2009;7(2):170-175.

3. Scott JG. Physicianship revisited [eletter]. http://www.annfammed. org/cgi/eletters/7/2/170\#10718, 23 Mar 2009. 
4. Stover S. Reclaiming our souls [eletter]. http://www.annfammed. org/cgi/eletters/7/2/170\#10639, 12 Mar 2009.

5. Dobkin PL. Physicianship [eletter]. http://www.annfammed.org/cgi/ eletters/7/2/170\#10693, 18 Mar 2009.

6. Kearslely JH. Medical Michaelangelos [eletter]. http://www. annfammed.org/cgi/eletters/7/2/170\#10701, 20 Mar 2009.

7. Wilson HJ. Medical students and healing [eletter]. http://www. annfammed.org/cgi/eletters/7/2/170\#10740, 1 Apr 2009.

8. Karlin PJ. Physician-healers' example is important for students [eletter]. http://www.annfammed.org/cgi/eletters/7/2/170\#10683, 17 Mar 2009.

9. Howe AL. With thanks from a patient advocate [eletter]. http:// www.annfammed.org/cgi/eletters/7/2/170\#10728, 27 Mar 2009.

10. Silverman PR. Some thoughts on Tom Egnew's paper [eletter]. http:// www.annfammed.org/cgi/eletters/7/2/170\#10696, 19 Mar 2009.

11. Farber $\mathrm{S}$. We need more physician healers [eletter]. http://www. annfammed.org/cgi/eletters/7/2/170\#10635, 12 Mar 2009.

12. TRACK discussion in response to: Stange KC. The problem of fragmentation and the need for integrative solutions. Ann Fam Med. 2009;7(2):100-103. http://www.annfammed.org/cgi/eletters/7/2/100. Accessed Apr 6, 2009.

13. TRACK discussion in response to: Valderas JM, Starfield $B$, Forrest $C B$ Sibbald B, Roland M. Ambulatory care provided by office-based specialists in the United States. Ann Fam Med. 2009;7(2):104-111. http:// www.annfammed.org/cgi/eletters/7/2/104. Accessed Apr 6, 2009.

14. TRACK discussion in response to: van Bokhoven MA, Koch $\mathrm{H}$, van der Weijden $T$, et al. Influence of watchful waiting on satisfaction and anxiety among patients seeking care for unexplained complaints. Ann Fam Med. 2009;7(2):112-120. http://www.annfammed. org/cgi/eletters/7/2/112. Accessed Apr 6, 2009.

15. TRACK discussion in response to: McDonald R, Roland M. Pay for performance in primary care in England and California: comparison of unintended consequences. Ann Fam Med. 2009;7(2):121-127. http:// www.annfammed.org/cgi/eletters/7/2/121. Accessed Apr 6, 2009.

16. TRACK discussion in response to: Cohen D, Coco A. Declining trends in the provision of prenatal care visits by family physicians. Ann Fam Med. 2009;720:128-133. http://www.annfammed.org/cgi/ eletters/7/2/128. Accessed Apr 6, 2009

17. TRACK discussion in response to: Coco A. How often do physicians address other medical problems while providing prenatal care? Ann Fam Med. 2009;7(2):134-138. http://www.annfammed.org/cgi/eletters/7/2/134. Accessed Apr 6, 2009.

18. TRACK discussion in response to: Jerant $A$, Chapman BP, Duberstein $\mathrm{P}$, Franks $\mathrm{P}$. Is personality a key predictor of missing study data? An analysis from a randomized controlled trial. Ann Fam Med. 2009;7(2):148-156. http://www.annfammed.org/cgi/eletters/7/2/148. Accessed Apr 6, 2009.

19. TRACK discussion in response to: Talati $R$, Baker WL, Pabilonia MS, White CM, Coleman Cl. The effects of barley-derived soluble fiber on serum lipids. Ann Fam Med. 2009;7(2):157-163. http://www. annfammed.org/cgi/eletters/7/2/157. Accessed Apr 6, 2009
20. TRACK discussion in response to: Solberg LI, Elward KS, Phillips WR, et al. How can primary care cross the quality chasm? Ann Fam Med. 2009;7(2):164-169. http://www.annfammed.org/cgi/eletters/7/2/164. Accessed Apr 6, 2009.

21. TRACK discussion in response to: Townsend JM. One last question: opening Pandora's Box? Ann Fam Med. 2009;7(2):176-177. http:// www.annfammed.org/cgi/eletters/7/2/176. Accessed Apr 6, 2009.

22. TRACK discussion in response to: Jeppesen KM, Coyle JD, Miser WF. Screening questions to predict limited health literacy: a crosssectional study of patients with diabetes mellitus. Ann Fam Med. 2009;7(1):24-31. http://www.annfammed.org/cgi/eletters/7/1/24. Accessed Apr 6, 2009.

23. TRACK discussion in response to: Zuidgeest MGP, van Dijk L, Spreeuwenberg $P$, et al. What drives prescribing of asthma medication to children? A multilevel population-based study. Ann Fam Med. 2009;7(1):32-40. http://www.annfammed.org/cgi/eletters/7/1/32. Accessed Apr 6, 2009.

24. TRACK discussion in response to: Parnes $B$, Smith PC, Gilroy $C$, et al. Lack of impact of direct-to-consumer advertising on the physician-patient encounter in primary care: a SNOCAP report. Ann Fam Med. 2009;7(1):41-46. http://www.annfammed.org/cgi/eletters/7/1/41. Accessed Apr 6, 2009.

25. TRACK discussion in response to: Wilkins T, LeClair B, Smolkin M, et al. Screening colonoscopies by primary care physicians: a metaanalysis. Ann Fam Med. 2009;7(1):56-62. http://www.annfammed. org/cgi/eletters/7/1/56. Accessed Apr 6, 2009.

26. TRACK discussion in response to: Gjerdingen D, Crow S, McGovern P, Miner M, Center B. Postpartum depression screening at well-child visits: validity of a 2-question screen and the PHQ-9. Ann Fam Med. 2009;7(1):63-70. http://www.annfammed.org/cgi/eletters/7/1/63. Accessed Apr 6, 2009.

27. TRACK discussion in response to: Post-Myocardial Infarction Depression Clinical Practice Guideline Panel. AAFP guideline for the detection and management of post-myocardial infarction depression. Ann Fam Med. 2009;7(1)71-79. http://www.annfammed.org/ cgi/eletters/7/1/71. Accessed Apr 6, 2009.

28. TRACK discussion in response to: Kuzel AJ, Skoch EM. Achieving a patient-centered medical home as determined by the NCQA-at what cost, and to what purpose? Ann Fam Med. 2009;7(1):85-86. http://www.annfammed.org/cgi/eletters/7/1/85. Accessed Apr 6, 2009.

29. TRACK discussion in response to: Spiegelhalter DJ. Understanding uncertainty. Ann Fam Med. 2008;6(3):196-197. http://www. annfammed.org/cgi/eletters/6/3/196. Accessed Apr 6, 2009.

30. TRACK discussion in response to: Galliher JM, Stewart TV, Pathak PK, Werner JJ, Dickinson LM, Hickner JM. Data collection outcomes comparing paper forms with pda forms in an office-based patient survey. Ann Fam Med. 2008;6(2):154-160. http://www.annfammed. org/cgi/eletters/6/2/154. Accessed Apr 6, 2009.

31. Nelson CE, Fann B, Buidi J, et al. Results of residency journal club discussion [eletter]. http://www.annfammed.org/cgi/eletters/7/1/ iii\#10576, 4 Feb 2009.

\section{CORRECTIONS}

Ann Fam Med 2009;7:274. DOI: 10.1370/afm.1013.

In the Association of Family Medicine Residency Directors' Family Medicine Update for the March/April issue of the Annals, "Innovation in Family Medicine Residency Training" (Ann Fam Med. 2009;7:182-183), the abbreviation for the National Institute for Program Director Development should be NIPDD.

The Correction in the print version of the March/April 2009 issue of the Annals (Ann Fam Med. 2009;7:181) is missing its article citation and digital object identifier number: Ann Fam Med 2009; 7:181. DOI: 10.1370/ afm.984. This line appears in the online version; therefore, the print version departs from the online version. 